\title{
Leon Nieścior
}

Cardinal Stefan Wyszyński University in Warsaw

ORCID: 0000-0003-4988-9667

\section{Passions and the Struggle Against Them According to Mark the Hermit ${ }^{1}$}

\begin{abstract}
Mark the Hermit, a monk from the $4^{\text {th }}$ century, active probably in Asia Minor, indicates in an original way that the cause of passion in man is forgetting about good thoughts (lèthē), carelessness (rhathymia) and ignorance (agnoia). This threefold evil is opposed by the following means: forgetfulness - by memory of good works, carelessness - by most sincere readiness, ignorance - by enlightened cognition. Nobody before him had ever dealt with the causes of passion in such a way and indicated such an antidote to them. In order to understand Mark the Hermit's theory, it is necessary to look in detail at this writer's teaching about passion and the ascetic fight against it. This article is devoted to this spiritually important issue.
\end{abstract}

Keywords: Mark the Hermit, Mark the Ascetic, asceticism, passions

$\mathrm{M}$ ark the Hermit wrote at a time when ascetic thought already had a considerable tradition. He did not have to define many concepts in his teaching on passions and work on them. He was keen to use the word $\pi \dot{\alpha} \theta 0 \varsigma$, which for him most often had a moral meaning. In our analysis we will limit ourselves to the writer's statements in which $\pi \dot{\alpha} \theta$ o $̧$ appears formally. The topic of passions

\footnotetext{
${ }^{1}$ This article is a revised and updated version of the article originally published in Polish: Leon Nieścior, "Namiętności i walka z nimi według Marka Eremity," Collectanea Theologica 89 (2019) no. 1, 101-114. Translated from Polish by Maciej Górnicki.
} 
in the teaching of our author has already been addressed in several monographs, as shown in the attached list of studies. However, no one has comprehensively analyzed this term.

\section{The Genesis of Passions}

The word "genesis" conveys well the first object of our investigation, which covers both the factors and the way passions originate and develop.

Our author states that ignorance of the causes of passions quickly leads to a fall. ${ }^{2}$ Therefore, probing into the causes is not a purely theoretical procedure, but has practical significance. A properly made diagnosis leads to appropriate measures. In his characteristic way, the writer often talks about loving or hating the "causes" (aitías) of passions, or, in principle, their object. Whoever gives in to these causes gives in to passions, even against his will. He who hates passions removes their causes. ${ }^{3}$ It is impossible to think about passions without having a liking for their causes. For example, those who do not care about human appreciation and, additionally, are indifferent to contempt, will not seek human glory, which is the cause of vanity. ${ }^{4}$

The factors causing a moral disease are to be sought primarily in man himself. They are not directly caused by external circumstances, such as temporal well-being. The righteous of the Old Covenant, such as Abraham, Job and David, were "impassively rich" and therefore pleasing to God, while others do not have riches, but nurture their passion in the desire to acquire them. ${ }^{5}$

Mark the Monk tries to point out the common cause of passions, but he does not ponder on this issue for too long. He refers to St Paul's statement that the root of all evil is greed for money (1 Tim 6:10), but this greed also exists thanks to other passions, namely vanity and [sensual] pleasure. ${ }^{6}$ Similarly, he states

${ }^{2} \mathrm{Cf}$. Marcus Eremita, De lege spirituali, 78.

${ }^{3} \mathrm{Cf}$. idem, De his qui putant se ex operibus iustificari, 111, PG 65, 945.

${ }^{4}$ Cf. ibidem, 114.

${ }^{5} \mathrm{Cf}$. idem, Consultatio intellectus cum sua ipsius anima, 3.

${ }^{6} \mathrm{Cf}$. idem, De lege spirituali, 103. 
elsewhere that the cause of all anger is vanity and pleasure. He who does not despise them will not overcome passions. ${ }^{7}$ It seems that the common denominator for moral illnesses is precisely the tendency to seek mundane pleasures. The common "mother" of passions is

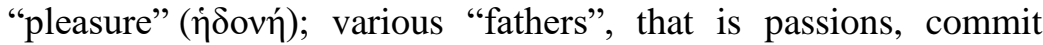
"adultery" with it. ${ }^{8}$ Even if some passion has been eradicated, the inclination to pleasure ( $\dot{\eta} \delta v \pi \alpha ́ \theta \varepsilon \imath \alpha)$ can once more awaken thoughts about old things. ${ }^{9}$

Elsewhere, the author points to other phenomena that give rise to the establishment of evil in the human interior. The deepest passions of the soul are forgetting good thoughts, carelessness and ignorance

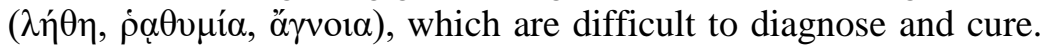
When man gives himself over to exaggerated activity, these passions obscure the spirit and make others creep in, causing the disappearance of God's fear and neglect of the good. ${ }^{10}$ These three form the basis for all the other passions. ${ }^{11}$ For Mark the Hermit, the unwise virgins (Matt 25:1-13) who took some oil to meet the bridegroom mean those who retain a certain virtue and correctness of conduct, but who, under the influence of carelessness, recklessness and ignorance, have lost their care for the inner purity of their soul. They did not look into the vessel of the soul with a caution, they did not notice the passions there. ${ }^{12}$

Forgetfulness, carelessness and ignorance can hardly be called passions in the strict sense, as in our author. More precisely, they are elements of a human attitude that leads to passion. Although in general, Mark uses the common term $\pi \alpha \dot{\theta} \theta \delta$, as we can see, he does not pay much attention to the precision of terms. Nonetheless, pointing to the three components that constitute every passion seems to be a valuable contribution to ancient ascetic thought. While the inclination to pleasure is a source of passion innate to man, the aforementioned failings seem to be his personal fault in the formation of a moral disease. As far as we can tell, nobody before

\footnotetext{
${ }^{7}$ Cf. ibidem, 102.

${ }^{8}$ Cf. ibidem, 100, PG 65, 917.

${ }^{9} \mathrm{Cf}$. idem, De baptismo, 11, PG 65, 1016.

${ }^{10} \mathrm{Cf}$. idem, Ad Nicolaum praecepta animae salutaria, 10.

${ }^{11}$ Cf. ibidem, 12; ibidem, 3.

${ }^{12}$ Cf. ibidem, 4.
} 
Mark the Hermit combined these three moral deficiencies into one source from which every passion flows. They appear later, clearly taken over from Mark, in a compilation work by an anonymous author entitled De virtutibus et vitiis. ${ }^{13}$ It is worth noting that this work, published under the name of such authorities as Ephrem the Syrian or John of Damascus, was read in the Byzantine environment, and around 1000 was rewritten perhaps by Stephen from Nicomedia under the name Syntagma ad quemdam politicum. ${ }^{14}$ Together with the popularisation of knowledge about passions in Eastern Christianity, some of Mark the Hermit's thoughts on the subject were passed on.

Looking for the cause of passion, the author seems to get to the heart of the matter in a certain longer text. He wonders why people differ in their way of thinking and acting. He answers this question in a descriptive manner. Not everyone is equally familiar with God's teachings, not everyone at the same time, in the same acts and in the same way rejects human glory and liking for pleasure. They do so depending on how much they believe in God, how much they put hope in future goods. They seek their own wisdom, not that which comes from faith in Christ and is expressed in putting the commandments into practice. They do not care to remove wrong thoughts through the humility of the heart. On the contrary, by a hidden predilection for pleasure, they seek human glory, wanting to please people. By giving in to pride, they want to show others their victories and successes. By doing so, they allow thoughts full of lust to grow, and through them - various passions. That is why, in fact, they do not achieve anything. The author appeals to the consciences of these people: Why do they not try to defend themselves against such bad thoughts? Even if they give in to these thoughts through no fault, still, while doing so they do not listen to the Word of God. God becomes incredible for them. It is by deed, word and thought that they bring various passions to themselves every day. If they love

${ }^{13}$ Cf. Pseudo-John of Damascus, De virtutibus et vitiis (fragmenta), PG 95, 88:

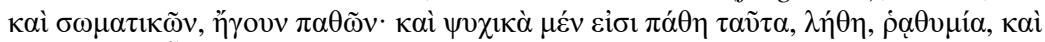

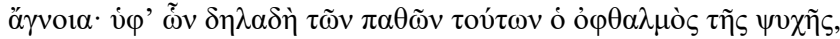

${ }^{14}$ Cf. D. Krausmüller, "Religious Instruction for Laypeople in Byzantium: Stephen of Nicomedia, Nicephorus Ouranos, and the Pseudo-Athanasian Syntagma ad quendam politicum," Byzantion 77 (2007), 239-250. 
them as if they were benefactors and not enemies, how do they prevent them from invading their interior? When, in turn, they accept the first bad thought, it will inevitably bring in the next ones. ${ }^{15}$

Passions are corporal and mindless mechanisms of evil, to which the soul has succumbed and has been attracted and enslaved by them. Such a fatal process has its stages: evoking bad thoughts - bad

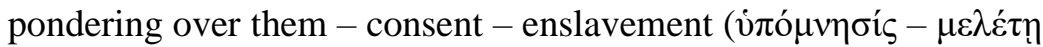

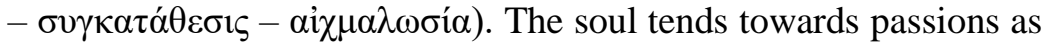
a result of previous inclinations and habits. ${ }^{16}$ If one notices that desires have been awakened and incline to passions, they must know that the spirit has already sought their object, turned its desires into action and grafted them in the heart. ${ }^{17}$ Just as a cloud does not come without a previous gust of wind, so passion will not arise without a previous thought. ${ }^{18}$

So the cause of the creation and development of passions is located in man, more precisely: in his mind, will and feelings. The inclination to pleasure arouses the matter of respective thoughts and makes one submit to them. This process intensifies, and man grows increasingly weaker in his faith, seeking good in something beyond God. In a certain place, Mark the Hermit considers the causation of man's will in the context of baptism. If, after baptism, we are overcome by some kind of sin, it is not because of the imperfection of baptism, but because we have voluntarily disregarded a commandment and succumbed to bad pleasures. ${ }^{19}$ Mark's teachings lead to the conclusion that he who sins after baptism does so because of personal guilt, and not because of the existence of

\footnotetext{
${ }^{15}$ Cf. Marcus Eremita, De baptismo, 14.

${ }^{16} \mathrm{Cf}$. idem, Ad Nicolaum praecepta animae salutaria, 1, PG 65, 1029; on the growth of evil leading to man's moral enslavement in the thought of Mark the Hermit; cf. I. Zajcev, Svjatootečeskoe učenie o glavnych momentach postepennogo razvitija grecha (sv. Ioann Lestvičnik, sv. Ioann Kassian, sv. Diadoch i sv. Mark Podwižnik), Moscow 1959 [typescript].

${ }^{17}$ Cf. Marcus Eremita, De lege spirituali, 180.

${ }^{18} \mathrm{Cf}$. ibidem, 181.

${ }^{19} \mathrm{Cf}$. idem, De baptismo, 2.
} 
some structure of evil that is a legacy of original $\sin .{ }^{20}$ Evil thoughts, too, are not a legacy of Adam's sin, but come from our free will, from our anger. ${ }^{21}$ If, conversely, we have power over passions, it is on the basis of our own will and not something else. ${ }^{22}$

The characteristics of passion emerge from some of the author's statements. We do not find a full description of this phenomenon, but individual remarks. Passions are forms of evil spilling out inside the heart. ${ }^{23}$ As we know, ancient Christian writers, following the ancient philosophy, interpreted passion in two ways: in the Stoic spirit, as enslavement of man, a moral disease that must be eradicated, or, in the Aristotelian-Platonic spirit, as a drive, a neutral tendency of nature to something that cannot be rid of but can be controlled. ${ }^{24}$ Mark the Hermit represents the first way of understanding passions. At one point the author states that there are eleven sinful passions. If someone loves one of them of one's own free will, it will fill the place of all the others. ${ }^{25}$ Unlike the fixed catalogue of the eight main passions listed by Evagrius of Pontus, the list of the various moral diseases in Mark the Hermit is not definite as to the count. The number eleven is just an example, because other numbers appear elsewhere. In another place, the author lists as much as thirty-two passions. ${ }^{26}$

The monk emphasises the difficulty of discerning vanity, for example. Being recognized by the others is always attractive, and consequently the passion for vain glory is hardly noticeable by those who succumb to it. Other passions typically make people humble themselves, while this one hides under the guise of piety. It is difficult to identify its mechanisms of temptation. ${ }^{27}$ Sometimes even

${ }^{20}$ Cf. O. Hesse, "Der Streit über die Wirkung der Taufe im frühen Mönchtum bei Makarios/Symeon, Markos Eremites und den Messalianern," in: D. Hellholm [et al.] (eds.), Ablution, Initiation, and Baptism: Late Antiquity, Early Judaism, and Early Christianity, Berlin-Boston 2011, 1326.

${ }^{21}$ Cf. O. Hesse, Der Streit über die Wirkung der Taufe..., op. cit., 1323.

${ }^{22}$ Cf. Marcus Eremita, De baptismo, 2.

${ }^{23} \mathrm{Cf}$. idem, Ad Nicolaum praecepta animae salutaria, 1.

${ }^{24}$ Cf. K.T. Ware, "The meaning of Pathos in Abba Isaias and Theodoret of Cyrus," Studia Patristica 20 (1989), 315-322.

${ }^{25} \mathrm{Cf}$. Marcus Eremita, De lege spirituali, 136.

${ }^{26} \mathrm{Cf}$. idem, Ad Nicolaum praecepta animae salutaria, 4.

${ }^{27}$ Idem, Disputatio cum quodam causidico, 9. 
behind a pious word there is a desire to present vanity as something good. Different paths of evil are interconnected and meet in vanity: disbelief (the mother of all), jealousy, hatred, rivalry, deceit, quarrelsomeness, hypocrisy, bias, pretence, slander, lies. For example, a sneaky man rebukes someone to gain more exposure for himself; when he makes a speech in court, he does so not for justice, but for retaliation; he slanders anonymously to hide himself as the perpetrator of slander; he seeks advantage and serves others to satisfy his hunger for recognition, and so on. ${ }^{28}$ Sometimes one passion displaces another. It can be that someone for a greater passion ( $\delta i \grave{\alpha} \mu \varepsilon i \zeta o v \alpha \dot{\eta} \delta v \pi \alpha ́ \theta \varepsilon ı \alpha v)$ will extinguish another, weaker one. He makes a futile effort, even if others praise him. ${ }^{29}$

A phenomenon often stressed by the writer is the revival of passions. When the spirit grows stronger and the soul renounces the transient inclination, the heart experiences anguish, drawn by the spirit and passion. ${ }^{30}$ In spite of the practised asceticism, the passions of the body continue to act as a result of the law of sin, which opposes the law of our spirit (Rom 7:23). ${ }^{31}$ When someone constantly rejects the passions he has forgotten thanks to the Holy Spirit, the Evil One plants them again. If somebody is already pure and sincerely hates passions, he may temporarily experience darkness because of temptations coming. But whoever is not pure and continues to seek pleasure, this temptation awakens the old weakness. ${ }^{32}$ Like oppression coming at the least appropriate time, that is, "in winter or on the Sabbath" (Matt 24:20), so the revolt of passion seizes the body of an elderly man or a soul dedicated to God..$^{33}$

There is a close relationship between what man feels and thinks and what he does. At a certain stage, passions do not go beyond the internal scope, but later on they also reveal themselves to the outside world. In this sense, some passions take the shape of different

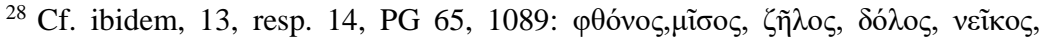

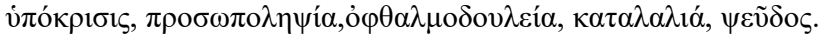

${ }^{29}$ Cf. idem, De lege spirituali, 101, PG 65, 917.

${ }^{30} \mathrm{Cf}$. idem, De his qui putant se ex operibus iustificari, 68.

${ }^{31} \mathrm{Cf}$. idem, Ad Nicolaum praecepta animae salutaria, 1.

${ }^{32} \mathrm{Cf}$. idem, De his qui putant se ex operibus iustificari, 140.

${ }^{33}$ Cf. ibidem, 70.
} 
thoughts and others - actions, even if the shapes and images themselves change. ${ }^{34}$ For example, vanity is manifested in the search for praise, while liking for pleasure in complaining about an incoming tribulation. ${ }^{35}$ Sometimes passions do not influence behaviour directly, but only indirectly. There are people who, while fulfilling the commandments on the outside, succumb to passions internally and thwart their good deeds through bad thoughts. ${ }^{36}$

The effects of passions were often the focus of attention from ancient ascetic writers. Mark the Hermit points out, following others, the consequences of vices: enslavement of the will and darkening of the mind. When passion induces one to do something, and takes control of the will, then it arises in the person who has succumbed to it even against his will. ${ }^{37}$ The mind is obscured by greed, vanity and pleasure. ${ }^{38}$ As a result of passion, the sight of a beautiful woman immediately arouses carnal lust. ${ }^{39}$ The author illustrates the fatal influence of passion with the example of anger. Such a state causes quarrels with brothers. Accumulated bad memories prevent pure prayer and lead the mind into captivity. They form "animal" thoughts about a brother, even though he has the same soul, subjecting the angry person to the action of evil spirits and leading his mind to sadness, doubt or carelessness. ${ }^{40}$ The passion for wrath ravages, disrupts and darkens the soul, making the human being similar to an animal. ${ }^{41}$

The author describes anger using the image of a tree and a house. This passion is supported by pride, which makes it practically indestructible. It is similar to the water that irrigates a devil tree

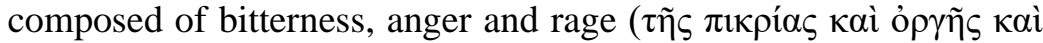
$\theta v \mu$ ṽ). Its fruit is wickedness ( $\alpha \nu 0 \mu i ́ \alpha)$. Only the "axe" of the Holy Spirit cuts the tree and throws it into the fire (Matt 3:10), and annihilates it. Such a man can be compared to a house made up of

\footnotetext{
${ }^{34} \mathrm{Cf}$. idem, De lege spirituali, 179.

35 Cf. ibidem, 144.

${ }^{36} \mathrm{Cf}$. ibidem, 170.

${ }^{37} \mathrm{Cf}$. idem, De his qui putant se ex operibus iustificari, 78.

${ }^{38} \mathrm{Cf}$. idem, De lege spirituali, 103.

${ }^{39} \mathrm{Cf}$. idem, Ad Nicolaum praecepta animae salutaria, 10.

${ }^{40} \mathrm{Cf}$. ibidem, 3.

${ }^{41}$ Cf. ibidem, 8 .
} 
many stones, meaning collected memories of various thoughts and deeds. $^{42}$

\section{Struggle Against Passions}

The author devotes a lot of space to the struggle against passions. In this respect our writer also lacks systematic reflection, but some of his remarks provide subtle indications. ${ }^{43}$

The general lifestyle geared towards asceticism is important. Whoever is engaged with warfare, let him not get entangled into civilian pursuits (2 Tim 2:4). The same is true of those who want to overcome their passions and let themselves get involved in various activities - they are similar to those who want to put out the fire with chaff. ${ }^{44}$ The author praises the addressee that he undertakes a spiritual struggle through restraint, reticence, a night watch and fervent prayer. ${ }^{45} \mathrm{He}$ recommends to another addressee that he should cultivate a life of celibacy and purity. ${ }^{46}$ Transformation, becoming sober and enlightenment through divine knowledge begins through frequent prayer, vigil, repentance and confession of guilt. $^{47}$

The monk stresses the vigilance about the first attacks of evil. Man could have asked God, when evil was still small, to avert it, and yet he did not do so, because he considered this small thing to be a trifle, not knowing that small leads to bigger, both in good and evil. ${ }^{48}$ Only at the first thought can the devil prompt us to do an evil deed to explore the very depths of our inner self, what it is inclined to do. ${ }^{49}$ The final decision belongs to man. It is therefore important not to allow the Evil One to do more. What is needed is decisiveness

\footnotetext{
${ }^{42}$ Cf. ibidem, PG 65, 1041.

${ }^{43}$ On liberation from internal bondage and the pursuit of spiritual freedom cf. I.-A. Khalifé, L'antropologie théologique de Marc l'Ermite. De l'esclavage intérieur à la liberté spirituelle, Roma 1949.

${ }^{44} \mathrm{Cf}$. idem, De lege spirituali, 109.

${ }^{45} \mathrm{Cf}$. idem, Ad Nicolaum praecepta animae salutaria, 1.

${ }^{46}$ Cf. ibidem, 7.

${ }^{47} \mathrm{Cf}$. ibidem, 3.

${ }^{48}$ Cf. idem, De paenitentia, 9.

${ }^{49} \mathrm{Cf}$. idem, De baptismo, 11.
} 
in rejecting the whispers of evil. Mark the Hermit encourages us to "hate" passions. We usually stop briefly at what we hate, but we are able to stop longer in our thoughts at what we love. If we hate some passion, the thoughts associated with it quickly go away. If something lasts longer, however, even though we hate it, it is because it has attracted us before. ${ }^{50}$ Virtue is the opposite of passion, ${ }^{51}$ so the former adherence to weakness must be replaced by the pursuit of virtue.

Typically, man has already been affected by some kind of soul disease in the past. Using the word "penance," Mark the Hermit describes a lifestyle that is a fight against passions. What keeps one on the right track is the effort of expiation and conversion. Penance is for everyone. It restores power over evil, allowing it to be seen as voluntary, even though it used to be involuntary, in order to stay away from it even more, hate passions and not to let them go into action. He who restricts penance returns to his old transgressions. ${ }^{52}$ Whoever has once freed himself from passions and then surrenders to the pressing evil, neglecting to fight and pray, will necessarily be conquered not only by that evil, but by other passions as well. He will be deprived of God's help, he will surrender to the tyranny of things to which he was previously subjected, giving over to even greater evil. ${ }^{53}$

Traces of previous moral diseases remain in the form of some inclination to evil which one renounced at some point. This susceptibility is an involuntary memory of the former evil. Even when one throws away all voluntary evil from the mind, passion still presents itself in the form of involuntary evil. It is necessary to undertake a fight against these involuntary passions which occur due to some special susceptibility $\left(\pi \rho{ }^{\prime} \lambda \eta \psi 1 \varsigma\right) .{ }^{54} \mathrm{He}$ who truly fights will not allow this susceptibility to develop again into voluntary passion, whereas the winner destroys it completely. ${ }^{55}$

\footnotetext{
${ }^{50} \mathrm{Cf}$. ibidem, 11.

${ }^{51}$ Cf. idem, Disputatio cum quodam causidico, 11, resp. 10.

${ }^{52} \mathrm{Cf}$. idem, De paenitentia, 12.

${ }^{53} \mathrm{Cf}$. ibidem, 8.

${ }^{54}$ Cf. idem, De lege spirituali, 139, PG 65, 921.

55 Cf. ibidem, 140.
} 
As noted before, for the author, three human attitudes are the cause of passions: forgetfulness, carelessness and ignorance. If he wants to overcome them, he should pray and return to himself with God's help, look into the depths of his heart and sense these three powerful means used by the devil. The following means oppose this threefold evil: forgetfulness - memory of good works, carelessness - most sincere readiness, ignorance - enlightened cognition $(\mu \nu \eta \dot{\eta} \eta \varsigma$

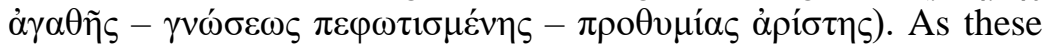
instructions were obtained not as a result of empty knowledge or goodwill alone, but thanks to God's power and the help of the Holy Spirit, such a person will experience being rescued from the slavery of evil. ${ }^{56}$ For example, those who have not gained knowledge of the truth and God's fear by God's grace will suffer damage not only because of passions but also due to drastic events. ${ }^{57}$

The author emphasises the role of meditation in liberating oneself from the bondage of vices. He gives more guidance on this subject in the letter Ad Nicolaum praecepta animae salutaria. The addressee, Nicolaus, regrets that he is overwhelmed by the passion of anger and desire. He therefore asks for a word of instruction and encouragement. The author points to the content previously given to the addressee for reflection, which will be useful in connection with asceticism, faith and God's grace, if the recipient of the teachings tries to act in accordance with reason and the cognition of God. A more zealous and constant fight must be taken against passions. ${ }^{58}$ Continuous zeal is recommended in the consideration of Christ's salvific instruction and His acts, from which one is dissuaded by either hidden evil or carelessness. Time should be spent usefully and in a spirit of gratitude. Good memories of this kind, which pierce the heart like a thorn, lead to confession, humility, thanksgiving, zeal, making amends in various ways and to

\footnotetext{
${ }^{56}$ Cf. idem, Ad Nicolaum praecepta animae salutaria, 13, PG 65, 1049. More on the role of memory, cognition and zeal in spiritual struggle cf. E. Faure, "Mémoire, connaissance et zèle dans le combat spirituel selon la Lettre à Nicolas attribuée à Marc le moine," Nouvelle Revue Théologique 4/139 (2017), 605-618.

${ }^{57} \mathrm{Cf}$. idem, De his qui putant se ex operibus iustificari, 181.

${ }^{58}$ Cf. idem, Ad Nicolaum praecepta animae salutaria, 1, PG 65, 1029: õ̃ $\pi \rho o ́ \tau \varepsilon \rho o v$

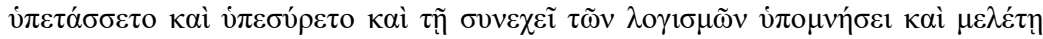

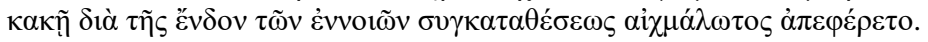


virtues in general. The soul that remembers the deeds of God, the lover of man, is saved from many a danger. ${ }^{59}$ When experiencing a lack of respect on the part of people, it is worth thinking about future God's glory. On the one hand, this will prevent worry and confusion, on the other one, the person will prepare himself to meet the Lord in a state of faithfulness and without reprimand. ${ }^{60}$ Mark

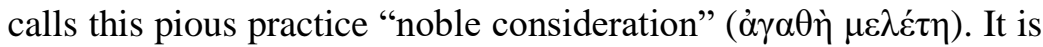
hindered by forgetfulness and carelessness. ${ }^{61}$ The spirit, mindful of the works performed by God, and even more so by grace, is permeated by love and longing. That is why Nicolas is supposed to remember the goodness of God in his personal life, and especially the fact that he was saved, together with two others, during a shipwreck during the storm, when he was on his way to Constantinople together with his mother after visiting the Holy Land. ${ }^{62}$

The author often refers to Christ's kenosis and in meditating it sees an efficient weapon for combating passions. Considering the Passion of Christ, as medieval writers will emphasize, serves well the struggle with sin. If anyone wants to overcome anger and pride, they must remember the humbling of the Son of Man, who descended from the heights of heaven and accepted human fate. ${ }^{63}$ When we reflect on the humbling of Christ, the whole edifice of wickedness, bitterness and wrath, based on pride will be demolished without difficulty, as it were, by its own power. ${ }^{64}$ Then we will realise that no one can be a true Christian if they are not prepared to carry their cross, and thus accept humiliation, contempt and harm, and reject human glory, honour and earthly pleasures. ${ }^{65}$

\footnotetext{
${ }^{59} \mathrm{Cf}$. ibidem, 2.

${ }^{60} \mathrm{Cf}$. idem, De his qui putant se ex operibus iustificari, 61.

${ }^{61} \mathrm{Cf}$. idem, Ad Nicolaum praecepta animae salutaria, 3, PG 65, 1032.

${ }^{62} \mathrm{Cf}$. ibidem, 6. At that time, Nicholas lost his mother, who died together with the entire crew of the ship. His upbringing will be taken care of by a certain Eleuter, who will shape his religious attitude, so that Santa becomes a monk. The author of the letter addresses him as a young monk; cf. O. Hesse, "Introduction," in: Markus Eremita, Asketische und dogmatische Schriften; eingeleitet, übersetzt und mit Anmerkungen versehen von O. Hesse, Stuttgart 1985, 79.

${ }^{63} \mathrm{Cf}$. Mark the Hermit, Ad Nicolaum praecepta animae salutaria, 8.

${ }^{64} \mathrm{Cf}$. ibidem, 10.

${ }^{65}$ Cf. ibidem, 3.
} 
Mark the Hermit emphasises the role of admonition in the struggle against passions. Whoever loathes admonition automatically surrenders to passions, and whoever likes it will make progress. ${ }^{66}$ Whoever, by arousing fear in the sinner, instils certain rules into him, he himself same will acquire the virtue opposing the defect he fought in the other one. ${ }^{67}$ Whoever mentions evil and in ill will mocks the other, will fall into the same passion according to the spiritual law (Rom 7:14). ${ }^{68}$ As sailors like the sunshine that opposes the chill of the wind, so the ones who succumb to passions yet fight them like the reprimand that opposes passions. ${ }^{69}$

Our writer cannot imagine asceticism without God's help. The theme of grace and God's help in self-improvement appears often. The author situates the fight against passions inside the redemptive work of Christ. Christ became like us in everything except sin, that is, passions (Heb 4:15). ${ }^{70}$ When the writer states that He accepted communion with us in body and spirit and "vouched

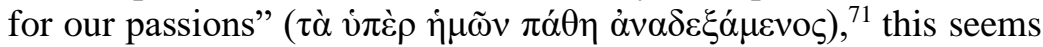
to indicate the justification that the Christian attains in Him. Mark the Hermit is a theologian of the Holy Spirit. The Spirit of God descends and enlightens the one who hates and overcomes passions, but brings darkness on the one who succumbs to them. ${ }^{72}$ The peace that comes after the liberation from passions is His work. ${ }^{73}$

\footnotetext{
${ }^{66} \mathrm{Cf}$. idem, De lege spirituali, 152.

${ }^{67} \mathrm{Cf}$. idem, De his qui putant se ex operibus iustificari, 171.

${ }^{68} \mathrm{Cf}$. ibidem, 171.

${ }^{69} \mathrm{Cf}$. ibidem, 69.

${ }^{70} \mathrm{Cf}$. idem, Ad Nicolaum praecepta animae salutaria, 9.

${ }^{71}$ Cf. idem, Disputatio cum quodam causidico, 20, resp. 14, PG 65, 1100.

${ }^{72} \mathrm{Cf}$. idem, De his qui putant se ex operibus iustificari, 110.

${ }^{73}$ Cf. idem, De lege spirituali, 193.
} 


\section{Bibliography}

\section{Sources}

Marcus Eremita, Ad Nicolaum praecepta animae salutaria, PG 65, $1028-1053$.

Marcus Eremita, Consultatio intellectus cum sua ipsius anima, PG 65, 1104-1109.

Marcus Eremita, De baptismo, PG 65, 985-1028.

Marcus Eremita, De his qui putant se ex operibus iustificari, PG 65, 929-965.

Marcus Eremita, De lege spirituali, PG 65, 905-929.

Marcus Eremita, De paenitentia, PG 65, 965-984.

Marcus Eremita, Disputatio cum quodam causidico, PG 65, 1072-1101

Pseudo-John of Damascus, De virtutibus et vitiis (fragmenta), PG 95, 85-97.

\section{English Translations}

Mark the Monk, Counsels on the spiritual life: vol. 1 transl., with notes and introd. by T. Vivian; vol. 2 transl., with notes and introd. by T. Vivian and A. Casiday; foreword by R. Williams, Crestwood NY 2009.

\section{Studies}

Faure E., "Mémoire, connaissance et zèle dans le combat spirituel selon la Lettre à Nicolas attribuée à Marc le moine," Nouvelle Revue Théologique 4/139 (2017), 605-618.

Hesse O., "Introduction," in: Markus Eremita, Asketische und dogmatische Schriften; eingeleitet, übersetzt und mit Anmerkungen versehen von O. Hesse, Stuttgart 1985, 1-151.

Hesse O., "Der Streit über die Wirkung der Taufe im frühen Mönchtum bei Makarios/Symeon, Markos Eremites und den Messalianern," in: D. Hellholm, T. Vegge, Ø. Norderval, C. Hellholm (eds.), Ablution, Initiation, and Baptism: Late Antiquity, Early Judaism, and Early Christianity, Berlin-Boston 2011, 1305-1345.

Jüssen K., "Dasein und Wesen der Erbsünde nach Markus Eremita," Zeitschrift für Katholische Theologie 62 (1938), 76-91.

Khalifé I.-A., L'antropologie théologique de Marc l'Ermite. De l'esclavage intérieur à la liberté spirituelle, Roma 1949. 
Krausmüller D., "Religious Instruction for Laypeople in Byzantium: Stephen of Nicomedia, Nicephorus Ouranos, and the PseudoAthanasian Syntagma ad quendam politicum," Byzantion 77 (2007), 239-250.

Ware K.T., "The meaning of Pathos in Abba Isaias and Theodoret of Cyrus," Studia Patristica 20 (1989), 315-322.

Zajcev I., Svjatootečeskoe učenie o glavnych momentach postepennogo razvitija grecha (sv. Ioann Lestvičnik, sv. Ioann Kassian, sv. Diadoch i sv. Mark Podwižnik), Moscow 1959, typescript. 